Ethos: Jurnal Penelitian dan Pengabdian Masyarakat, Vol 9 No.2, Juni 2021: 169-177

\title{
Penerapan Teknologi Pengolahan Limbah Cangkang Kerang Hijau SEBAGAI PAKAN TERNAK DAN IKAN \\ ${ }^{1}$ Kartono, ${ }^{2}$ Mukarto Siswoyo, ${ }^{3}$ Bukhori \\ ${ }^{1,2,3}$ Universitas Swadaya Gunung Jati (UGJ), Cirebon, Jawa Barat, Indonesia \\ email:1kartono.unswagati@gmail.com; ${ }^{2}$ Muksis2000@yahoo.com; ${ }^{3}$ bukhoricrb@gmail.com
}

\begin{abstract}
Environmental problems in Muara Village, Suranenggala Subdistrict, Cirebon Regency, are accumulated waste of green mussel shells. The objectives of this PKM activity are: 1) to deal with the accumulation of green mussel shells as feed ingredients / fish pelets by applying technology, namely; hammer mill machines, mixer machines, pelet extruders, and 2) to improve the welfare of the community from the activities of making fish feed / pelets. The method used is Participaroty Action Rural (PRA) which is one of the Participaroty Action Research methods. This method prioritizes community participation, identifying problems, compiling programs to plan solutions together. The location of the activity was carried out in the fishermen group in Muara Village, Suranenggala District, Cirebon Regency. The results of the application of technology for the process of making animal feed carried out in Muara Village can create new businesses for community groups, especially fishermen groups, so that it has implications for increasing welfare for the surrounding community. Based on the results of monitoring and evaluation, it is concluded that the application of appropriate technology in overcoming the accumulation of green mussel shell waste can create a new business, namely UKM making fish feed / pelets which in turn can improve welfare for the community.
\end{abstract}

Keywords: SMEs, appropriate technology

\begin{abstract}
Abstrak. Permasalahan lingkungan di Desa Muara Kecamatan Suranenggala Kabupaten Cirebon adalah menumpuknya limbah cangkang kerang hijau. Tujuan dari kegiatan PKM ini adalah 1) untuk menanggulangi menumpuknya limbah cangkang kerang hijau sebagai bahan pakan/pelet ikan dengan penerapan teknologi, yaitu mesin hammer mill, mesin mixer, pelet extruder; dan 2) untuk meningkatkan kesejahteraan masyarakat dari kegiatan pembuatan pakan/pelet ikan. Metode yang digunakan adalah Participaroty Action Research (PAR). Metode ini mengutamakan partisipasi masyarakat, mengidentifikasi masalah, dan menyusun program merencanakan solusi bersama-sama. Lokasi kegiatan dilaksanakan pada kelompok nelayan di Desa Muara, Kecamatan Suranenggala, Kabupaten Cirebon. Hasil dari penerapan teknologi untuk proses pembuatan pakan ternak yang dilakukan di Desa Muara dapat memunculkan usaha baru bagi kelompok masyarakat, khususnya kelompok nelayan sehingga dapat berimplikasi terhadap meingkatnya kesejahteraan bagi masyarakat sekitar. Berdasarkan hasil monitoring dan evaluasi disimpulkan bahwa penerapan teknologi tepat guna dalam menanggulangi menumpuknya limbah cangkang kerang hijau dapat menciptakan usaha baru, yaitu UKM pembuatan pakan/pelet ikan yang pada akhirnya dapat meningkatkan kesejahteraan bagi masyarakat.
\end{abstract}

Kata Kunci: UKM, Teknologi tepat guna

\section{Pendahuluan}

Secara geografis, Kabupaten Cirebon mempunyai posisi yang cukup strategis karena berlokasi di pantai utara Jawa sebagai penghubung antara Jakarta dengan kota-kota besar di wilayah Jawa dan kota-kota di sekitar Cirebon. Hal ini 
ditunjukkan dengan adanya ruas jalan tol Cikampek-Palimanan (Cipali), Palimanan-Kanci (Palikanci), dan Kanci-Pejagan. Jalan tol ini merupakan bagian dari jalan tol lintas Jawa.

Oleh sebab itu, tidaklah heran jika Cirebon sangat cocok dijadikan kota transit bagi wisatawan dari Jakarta menuju ke Jawa Tengah (Zahroh, Riani, \& Anwar, 2019). Cirebon memiliki ragam potensi yang dapat dinikmati oleh para wisatawan, di antaranya, kuliner khasnya, seperti empal gentong, tahu gejrot, nasi jamblang, nasi lengko yang sangat menjadi kuliner andalan bagi para wisatawan. Selain daya tarik kuliner, Cirebon juga memiliki potensi lain, yaitu batik trusmi, wisata budaya, dan religi, seperti Keraton Kasepuhan, Keraton Kanoman, Situs Gunung Jati, dan Gua Sunyaragi.

Potensi besar lainnya yang dimiliki oleh Kabupaten Cirebon adalah dimilikinya potensi sumber daya alam, seperti kekayaan hasil laut, yaitu ikan laut dan biota laiut lainya (Statistik, 2017). Seperti di Desa Muara Kecamatan Suranenggala Kabupaten Cirebon sebagian masyarakatnya berprofesi sebagai nelayan dengan membudidayakan hasil laut untuk dijadikan sebagai sumber ekonomi keluarga, seperti budi daya kerang hijau dan biota laut lainnya. Budi daya kerang hijau ini terletak diperbatasan antara air tawar dan air asin dan mampu menghasilkan 2 sampai 3 ton per lokalnya dan biasa dihargai Rp 2.000 $\mathrm{Rp} 3.000 / \mathrm{kg}$ untuk kerang hijau yang kotor (tanpa sortir) dan Rp 6.000/kg untuk kerang hijau yang sudah disortir.

Di Desa Muara terdapat pengepul daging kerang hijau yang biasanya disalurkan ke bandar dengan

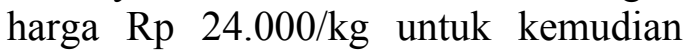
disalurkan lagi ke agen dengan harga $\mathrm{Rp} 30.000 / \mathrm{kg}$ dan didistribusikan oleh agen ke berbagai daerah, seperti Jakarta, Bandung, Surabaya, dan sebagainya.
Menurut nelayan kerang hijau, keuntungan yang didapat dari ternak kerang hijau per bulannya mencapai $\mathrm{Rp}$ 500.000,- terlebih jika musim hujan, biasanya kerang hijau diperoleh lebih banyak dengan kisaran paling sedikit 20 $\mathrm{kg}$ dan paling banyak 1 kuintal.

Kerang hijau merupakan sumber protein yang sangat murah dan kaya akan kalsium (Sata Yoshida Srie Rahayu, 2015), asam amino essensial, terutama arginin, leusin, dan lisin (Kurniasih, Rahmat, Handoko, \& Afif Zuhri, 2017). Dari budi daya kerang hijau selain diambil dagingnya juga dapat dimanfaatkan cangkang kerang hijau. Cangkang kerang mengandung kalsium tinggi sehingga dapat dimanfaatkan sebagai pakan ternak (Widiyanti et al., 2019). Namun demikian, saat ini masyarakat lebih memanfaatkan kerang atau hewan laut tersebut untuk diambil dagingnya saja. Belum dimanfaatkan untuk dijadikan komoditas lain yang memiliki nilai ekonomi yang tinggi, seperti produk hiasan atau kerajinan tangan, dan produk pakan ikan/pelet.

Aktivitas pengolahan kerang hijau yang dilakukan oleh kelompok nelayan di Desa Muara Kecamatan Suranenggala Kabupaten Cirebon, menimbulkan beberapa persoalan, yaitu terjadinya penumpukan limbah kulit kerang hijau yang dibuang dipinggir sungai, menimbulkan bau yang tidak sedap, serta mengundang datangnya berbagi sumber penyakit, seperti; penyakit pecernaan, penyakit perut, malaria, dan lainnya. Selain itu, penumpukan kulit kerang akan menjadi sarang hidupnya bakteri coli sehingga akan menimbulkan wabah muntaber atau diare (Kurniasih et al., 2017). Selain permasalahan menumpuknya limbah cangkang kerang hijau, kelompok nelayan di Desa Muara juga belum memiliki pengetahuan dan teknologi tentang bagaimana cara 
mengolah limbah cangkang kerang untuk dijadikan produk lain, seperti pakan/pelet ikan.

$$
\text { Limbah kerang hiaju }
$$

sesungguhnya dapat dimanfaatkan sebagai bahan pakan/pelet ikan. Pengolahan limbah cangkan kerang hijau tentu membutuhkan inovasi dan kreativitas yang dapat membantu bagaimana pemanfaatan limbah tersebut, misalnya, dengan penggunaan atau pemanfaatan teknologi tepat guna yang dapat meningkatkan produktivitas usaha bagi UMKM (Astuti, Kumayah, \& Agustina, 2020); (Hindun, Mulyono, \& Husamah, 2019); (Rahayu, Purnomo, Budiarti, \& Hidayati, 2019).

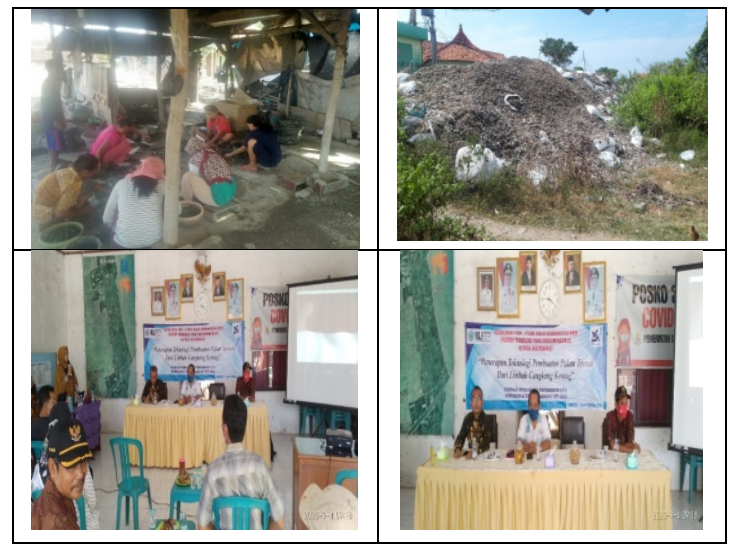

Gambar 1. Aktifitas pengupasan kerang hijau dan limbah cangkang kerang hijau, serta sosialisasi kegaiatan PKM PTDM Di Desa Muara Kecamatan Suranenggala Kab.Cirebon.

Dari gambar di atas nampak jelas bahawa adanya penumpukan limbah cangkang kerang hijau yang sangat banyak sebagai dampak dari kegiatan usaha pengupas daging kerang hijau yang dilakukan oleh kelompk nelayan tersebut.

Pemanfaatan cangkang kerang secara optimal akan mampu menghasilkan nilai ekonomis yang tidak kalah tinggi dan menambah nilai guna limbah menjadi produk yang bernilai ekonomis (Afrian et al., 2019). Kerang hijau dapat dimanfaatkan dengan dijadikan produk-produk baru. Hal itu dapat dijadikan peluang bisnis baru yang prospektif dan turut menyukseskan program pengembangan produk hasil perikanan dan dengan inovasi produk dari kerang hijau juga mempunyai peluang dikembangkan menjadi komoditi ekspor (Murdinah, 2009).

Pemanfaatan kulit cangkang kerang hijau juga bertujuan untuk mengurangi sampah cangkang kerang yang menjadi sumber permasalahan. Saat ini limbah cangkang kerang selama ini lebih banyak dimanfaatkan sebagai bahan kerajinan, seperti sebagai materi hiasan dinding atau materi desain interior (Agustini, Fahmi, Widowati, \& Sarwono, 2011), seperti lampu hias dan bentuk lainnya yang bernilai ekonomis tinggi. Padahal, kulit kerang dapat juga dimanfaatkan sebagai campuran pakan ternak (Agustini et al., 2011). Hal ini dapat dilakukan dengan inovasi dan kreativitas dari kelompok masyarakat yang didukung dengan penggunaan teknologi yang tepat guna untuk menunjang kegiatan ekonomi masyarakat tersebut.

Oleh karena itu, untuk menanggulangi menumpuknya limbah kerang, kulit kerang dimanfaatkan sebagai bahan pakan ternak ikan/pelet dan untuk menambah kegiatan ekonomi baru bagi kelompok nelayan.

Berdasarkan fenomena di atas, penerapan teknologi tepat guna yang dilakukan terhadap kelompok nelayan Muara Ilir Desa Muara, Kecamatan Suranenggala, Kabupaten Cirebon difokuskan untuk memberdayakan UMKM agar mampu mengelola limbah cangkang kerang hijau untuk diolah sehingga menjadi produk ekonomi yang tinggi, yaitu dengan membuat pakan/pelet ikan.

Adapun tujuan program kegiatan PKM ini adalah 1) untuk menanggulani menumpuknya limbah kerang dengan memanfaatkan kulit kerang sebagai 
bahan pakan/pelet ikan dan 2) untuk meningkatkan kesejahteraan masyarakat.

Publikasi hasil kegiatan PKM ini diharapkan dapat dijadikan rujukan bagi stakeholder terkait dalam menyusun kebijakan dan menanggulangi limbah cangkang kerang hijau dan upaya meningkatkan kesejahteraan masyarakat melalui penerapan teknologi tepat guna. Selain itu, hasil publikasi ini diharapkan dapat menjadi referensi bagi para peneliti, khusunya terkait dengan model peningkatan kesejahteraan masyarakat.

\section{Metode Ilmiah}

Metode yang digunakan adalah metode PRA (Partisipatory Rural Appraisal) yang meliputi pembekalan teori, praktik, dan demonstrasi yang selanjutnya dilakukan monitoring dan evaluasi secara intensif sehingga keberhasilan program dapat dilihat perkembangannya (Agatha Sih Piranti1, Diana RUS Rahayu, 2020), (Arief, Astuti, \& Andriyanto, 2016). Adapaun metode pelaksanaan dilakukan dengan beberapa tahapan, yaitu

1. Survey lokasi dilakukan di Desa Muara, Kecamatan Suranenggala, Kabupaten Cirebon.

2. Sosialisasi kegiatan dilakukan terhadap kelompok nelayan dan tokoh masyarakat yang ada di Desa Muara tentang kegiatan PTDM yang dilakukan oleh tim pelaksana.

3. Pelatihan produk olahan pakan/pelet ikan dari cangkang kerang hajau.

4. Pendampingan kewirausahaan, manajemen bisnis, menajamen keuangan, produksi, dan pemasaran berbasis tekonologi bagi mitra, yaitu Kelompok Nelayan di Desa Muara.
5. Melakukan bimbingan dan pendampingan teknis terkait penggunaan alat teknologi.

6. Aplikasi penggunaan produk teknologi.

Monitoring atau pengawasan terhadap kelompok Mitra di Desa Muara sebagai mitra dalam kegiatan PTDM.

\section{Hasil dan Pembahasan}

Kegiatan PKM melalui penerapan teknologi pengolahan limbah cangkang kerang hijau sebagai pakan ternak ikan yang dilaksanakan sejak bulan Juli - November 2020. Kegiatan dilakukan kepada kelompok nelayan di Desa Muara, Kecamatan Suranenggala, Kabupaten Cirebon. Sesuai dengan tahapan pelaksanaan kegiatan pada tahap pertama, tim PKM melakukan survei lokasi dilakukan terhadap mitra. Hal ini dilakukan untuk mendapatkan gambaran dan permasalahan yang dihadapi oleh mitra dalam hal ini kelompok nelayan Muara Ilir dan Sekar Muara di Desa Muara. Dari hal survei sebagai proses mengidentifikasi permasalahan, mitra tim mendapat beberapa permasalahn yang dihadapi oleh mitra, yaitu menumpuknya limbah kerang hijau yang sangat menggangu lingkungan.

Pada kegiatan kedua PKM ini, yaitu sosialisasi yang dilakukan terhadap kelompok nelayan dan tokoh masyarakat yang ada di Desa Muara tentang kegiatan PTDM dilakukan oleh tim pelaksana. Pada proses sosialisasi ini, tim memberikan gambaran terkait dengan beberapa hal, yaitu cara mengelola limbah cangkang kerang hijau yang dapat dijadikan produk lain, seperti pakan/pelet ikan atau produk hiasan. Alhasil, kelompok mitra mengetahui bahwa limbah cangkang kerang dapat dimanfaatkan untuk pengolahan pakan/pelet ikan sehingga 
mereka mendapatkan sumber ekonomi baru.

Tahapan ketiga dari kegiatan PKM ini adalah memberikan pelatihan produk olahan pakan/pelet ikan dari cangkang kerang hajau. Hal ini dilakukan agar mitra memiliki pengetahuan dan kemampuan untuk dapat melakukan pengolahan limbah cangkang kerang hijau untuk dijadikan produk pakan/pelet ikan. Kegiatan pelatihan pembuatan pakan ikan/pelet ikan ini dilakukan dengan menggandeng mitra lain, yaitu Dinas Kelautan dan Perikanan Kabupaten Cirebon. Dari hasil pelatihan, mitra memiliki kemampuan tentang bagaimana cara membuat pakan/pelet ikan dari limbah cangkan kerang hijau, baik dari segi komposisi bahan yang digunakan maupun teknik pencampuran bahan yang sesaui dengan kandungan gizi.

Setelah melakukan kegiatan pelatihan produk olahan pakan/pelet ikan dari cangkang kerang hajau, tahap keempat dalam kegiatan PKM adalah melakukan pendampingan kewirausahaan, manajemen bisnis, menajamen keuangan, produksi, dan pemasaran berbasis tekonologi bagi mitra. Kegiatan pendampingan kewirausahaan dan manajemen bisnis dilakukan dengan tujuan agar tumbuh motivasi mitra untuk melakukan usaha yang baik dan menguntungkan secara kontinu. Dari kegiatan pendampingan kewirausahaan dan manajemen bisnis atau usaha yang telah lakukan, beberapa capaian yang dicapai oleh mitra adalah :

a. Kelompok nelayan memiliki kemampuan dalam menghasilkan produk pakan ternak yang inovatif dan bernilai jual tinggi.

b. Inovasi lain yang ada pada mitra adalah sudah adanya produk pakan ternak atau pelet ikan dari limbah cangkang kerang hijau. c. Kemampuan, pengetahuan, dan semangat wirausaha mitra.

d. Memiliki kemampuan dalam bidang pembukuan sederhana kelompok mitra.

e. Adanya pengetahuan dan kemampuan mitra terkait dengan manajemen usaha, terutama manajemen pemasaran.

f. Mitra mampu menentukan harga pokok produk (HPP) sehingga laba dan rugi sangat mudah untuk diketahui.

Pada tahap kelima adalah melakukan pembimbingan dan pendampingan teknis terkait penggunaan alat teknologi yang diberikan, yaitu berupa :

a. Hammer Mill penggerak diesel 16 HP. Alat ini memiliki fungsi menghaluskan bahan-bahan, seperti jagung dan cangkang kerang.

b. Mixer dengan penggerak motor listrik $3 \mathrm{HP}$, dalam menjaga gizi pakan ternak, pakan ternak dari bahan limbah cangkang kerang perlu ada pencampuran (mixing) dengan berbagai bahan pakan pada umumnya, seperti dedak, jagung, dan lain-lain. Akibatnya, dalam proses pencampuran tersebut dibutuhkan alat mixing yang dinamakan mixer sebagai alat pencampur antara bahanbahan satu dengan lainnya.

c. Mesin Pelet Extruder penggerak diesel $16 \mathrm{Hp}$. Diameter poros motor penggerak berukuran 20 $\mathrm{mm}$ sedangkan diameter poros pencetak pelet tipe extruder berukuran $35 \mathrm{~mm}$. Penggerak memakai sabuk $\mathrm{V}$ tipe $\mathrm{A}$ berjumlah 1 buah untuk jarak antar poros $600 \mathrm{~mm}$.

Kegiatan pembimbingan dan pendampingan teknis dilakukan agar mitra dapat menggunakan dan mengoperasikan penggunaan mesin atau 
alat-alat yang digunakan untuk mengolah limbah cangkang kerang hijau menjadi produk pakan/pelet ikan. Kegiatan pendampingan penggunaan alat juga dimaksudkan untuk memberikan standar operasional prosedur dari beberapa alat teknologi yang diberikan. Agar selain dapat menggunakan, hal itu juga dapat mengetahui bagaimana melakukan perawatan terhadap teknologi yang digunakan.

Tahap keenam dalam pelaksanaan PKM ini adalah aplikasi Penggunaan Produk Teknologi yang didesiminasikan Kepada Masyakat (PTDM) berupa mesin hammer mills, mesin mixer, dan pelet extruder ke mitra. Hal ini diberikan untuk mendukung kegiatan nelayan agar lebih inovatif dalam menghasilkan produk sehingga produk pakan ternak atau pelet ikan dapat memiliki nilai ekonomi yang dapat bermanfaat bagi mitra. Dari penerepan teknologi ini kelompok mitra telah berhasil membuat pakan/pelet ikan dari limbah cangkang kerang hijau. Untuk fase awal-awal produk pakan/pelet ikan dapat diberikan kepeda para nelayan yang memiliki budi daya ikan laut dan ikan tawar yang ada di Desa Muara. Selanjutnya, kelebihan dari serapan produk pakan/pelet ikan tersebut dapat dijual keluar desa melalui BUMDES di Desa Muara. Selain itu, produk tepung dari limbah cangkang kerang hijau dapat juga dijual ke perusahaan pakan ternak yang ada di Cirebon. Oleh karena itu, adanya penerapan teknologi yang digunakan untuk pembuatan pakan/pelet ikan telah menciptakan sumber ekonomi atau UMKM baru yang ada di Desa Muara dengan harapan ke depan dapat menyerap tenaga kerja lebih banyak lagi dan berdampak juga terhadap meningkatkanya kesejahteraan bagi masyarakat nelayan di Desa Muara.
Pada tahap akhir dari kegiatan PKM ini adalah melakukan monitoring evaluasi terhadap kelompok Mitra. Dari hasil monitoring dan evaluasi di lapangan diketahui bahwa mitra telah memahami bahwa cara untuk melakukan pengolahan limbah cangkang kerang hijau yang tadinya menumpuk begitu saja dan sangat kumuh. Sekarang, hal itu sudah digunakan oleh kelompok masyarakat untuk diolah menjadi produk pakan/pelet ikan. Dari kegiatan monev juga sudah adanya pengelolaan hasil produksi pakan/pelet ikan yang dikelola oleh kempok nelayan dan BUMDES sebagai pemasar dari produk pakan/pelet ikan. Hal ini tentu menunjukkan bahwa keberhasilan program sesuai dengan harapan dari kegiatan PKM yang sesuai dengan permasalahan yang dihadapi mitra.

Beberapa faktor yang sangat mendukung dari pelaksanaan kegiatan PKM yang dapat mendukung keberhasilan kegiatan kepada mitra adalah :

1. Teknologi sederhana sehingga dapat digunakan oleh mitra dengan sangat mudah.

2. Sumber bahan baku, yaitu cangkang kerang hijau tersedia sangat banyak sehingga menduung untuk operasi usaha pakan atau pelet ikan

3. Sebagian besar masyarakat Desa Muara berprofesi sebagai nelayan sehingga sangat cocok dengan dilakukan kegiatan PKM melalui penerapan teknologi tepat guna.

4. Adanya BUMDES di Desa Muara sehingga hasil produksi diharapkan dapat dipasarkan melalui BUMDES.

Namun, dari pelaksanaan kegiatan PKM yang dilaksanakan kepada mitra terdapat beberapa faktor yang menjadi hambatan dalam 
melaksanakan kegiatan PKM, yaitu; Pertama, teknologi baru yang digunakan oleh kelompok nelayan Desa Muara sehingga masih butuh waktu dalam operasional yang sesuai SOP. Kedua, kelompok nelayan/mitra belum tampak jiwa wirausahanya sehingga tetap butuh support dan pendampingan yang kontinu dari akademisi. Ketiga, usaha pengolahan pakan ternak atau pelet yang berbahan baku limbah cangkang kerang hijau merupakan usaha rintisan dari nol sehingga membutuhkan ketekunan bagi tim PKM untuk terus melakukan kegiatan tridarma pergurungan tinggi terhadap mitra kelompok.

Oleh karena itu, untuk selanjutkan perlu dilakukan pemberdayaan terhadap mitra kelompok nelayan, yaitu :

a. Menyambungkan jejaring bisnis mitra dengan mitra usaha lain sehingga produk yang dihasilkan dapat terus dikenalkan kepada masyarakat luas.

b. Melakukan kegiatan PKM lanjutan baik. Hal ini dilakukan agar kegiatan yang sudah dilakukan melalui penerapan teknologi dapat terus dikembangkan dengan model lain apakah itu pemberdayaan atau lainnya.

c. Memberikan Akses lembaga pembiayaan yang bertujuan untuk memberikan informasi dan mendorong UMKM untuk memanfaatkan akses permodalan melalui perbankan, koperasi, atau CSR BUMN.

\section{Kesimpulan dan Saran}

\section{Kesimpulan}

Limbah cangkang kerang hijau dapat berfungsi sebagai asupan kalsium, fosfor, dan protein yang berfungsi sebagai sumber protein bagi pakan ikan/pelet. Melalui penerapan teknologi, limbah cangkang kerang hijau dapat dijadikan produk pakan/pelet ikan sehingga hal ini secara efektif dan efisien dapat mengatasi permasalahan lingkungan yang diakibatkan limbah cangkang, dapat menghemat biaya pakan/pelet ikan bagi kelompok nelayan, menjadikan sumber ekonomi atau kegiatan usaha baru bagi kelompok nelayan atau BUMDES, serta meningkatkan kesejahteraan ekonomi kelompok nelayan dengan menjual pakan ternak dari bahan limbah cangkang kerang hijau.

\section{Saran}

Dalam pengolahan limbah cangkang kerang hijau dengan penerapan teknologi yang diterapakan, sebaiknya diperhatikan ukuran partikel butrian gilingan dan bahan bahan pencampuran pakan ternak untuk meningkatkan daya cerna dan gizi serta efektivitas - efisiensi penggunaan pakan. Kegiatan pendampingan selanjutnya dalam bentuk program lain sehingga bisa menjadi solusi bagi masyarakat di Desa Muara, khusunya kelompok nelayan dalam menciptakan kegiatan ekonomi baru, yaitu pengolahan limbah cangkang kerang hijau menjadi olahan pakan ternak atau pelet ikan yang inovatif dan kualitas yang baik.

\section{Ucapan Terima Kasih}

Terima kasih kepada Kemenritek/BRIN melalui Lembaga Pengabdian Masyarakat Universitas Swadaya Gunung Jati (LPM UGJ) yang telah memberikan support, baik pendanaan maupun sarana prasarana untuk terselenggaranya PKM PTDM ini. 


\section{DAFTAR PUSTAKA}

Afrian, R., Islami, Z. R., Suciani, A., Rahmadi, M. T., Geografi, P. P., Samudra, U., \& Barat, L. (2019). Produk Lampu Hias cangkang padat cangkang tiram yang dihasilkan. 1(1), 50-55.

Agatha Sih Piranti1, Diana RUS Rahayu, G. W. (2020). Transfer Teknologi Pembuatan Pelet Organik Untuk Pakan Ikan. Dinamika Journal, 2(2), 25-33. https://doi.org/2686-2158

Agustini, T. W., Fahmi, A. S., Widowati, I., \& Sarwono, A. (2011). Pemanfaatan Limbah Cangkang Kerang Simping (Amusium pleuronectes) Dalam Pembuatan Cookies Kaya Kalsium. Pemanfaatan Limbah Cangkang Kerang Simping (Amusium Pleuronectes) Dalam Pembuatan Cookies Kaya Kalsium, 16(1), 8-13. https://doi.org/10.17844/jphpi.v14i1 .3423

Arief, M. R., Astuti, P., \& Andriyanto, T. (2016). Ipteks Bagi Kewirausahaan ( $I b K)$ Di Universitas Nusantara PGRI KedirI. 13, 1-8.

Astuti, R. P., ; Kumayah, S., \& Agustina. (2020). Dinamika Transportasi Berbasis Online Di Era Revolusi Industri 4.0. SAINS: Jurnal Manajemen Dan Bisnis, XII(216-231). Retrieved from https://jurnal.untirta.ac.id/index.php/ jsm/article/view/6840/5625

Hindun, I., Mulyono, M., \& Husamah, H. (2019). Pemanfaatan Teknologi Tepat Guna Berbasis Solar Cell untuk Mengatasi Permasalahan IRT Nelayan Sapeken Kabupaten Sumenep. International Journal of Community Service Learning, 3(4), 198.

https://doi.org/10.23887/ijcsl.v3i4.2 1791
Kurniasih, D., Rahmat, M. B., Handoko, C. R., \& Afif Zuhri. (2017). Pembuatan Pakan Ternak dari limbah Cangkang Kerang di Desa Bulak Kenjeran Surabaya. Seminar MASTER 2017 PPNS, 159164.

Murdinah, M. (2009). Penanganan Dan Diversifikasi Produk Olahan Kerang Hijau. Squalen Bulletin of Marine and Fisheries Postharvest and Biotechnology, 4(2), 61. https://doi.org/10.15578/squalen.v4i 2.149

Rahayu, S. S., Purnomo, A., Budiarti, V. S. A., \& Hidayati, N. (2019). Penerapan teknologi tepat guna pengelolaan sampah berbasis masyarakat menuju desa mandiri energi di Desa Banjarsari Kecamatan Gajah Kabupaten Demak. Seminar Nasional Hasil Pengabdian Masyarakat UAD, 1(September), 791-796.

Sata Yoshida Srie Rahayu. (2015). Pemanfaatan Tepung Cangkang Kerang Sebagai Bahan Fortifikan Pada Keripik Jagung Yang Dikonsumsi Anak Dan Remaja. Fitofarmaka, 5(2), 41-48.

Statistik, B. P. (2017). Laporan perkembangan UMKM di Indonesia. $B P S$.

Widiyanti, A., Ulfindrayani, I. F., Prayogi, Y. R., Arif, S., Fitria, A., Ningsih, L., ... Sidoarjo, U. (2019). Pemanfaatan Limbah Cangkang Kerang Sebagai Pakan Ternak Berkualitas Di Desa Tambak Cemandi Sidoarjo. Journal of Science and Social Development, 2(2).

Zahroh, A., Riani, E., \& Anwar, S. (2019). Analysis of Water Quality for Green Mussel Cultivation in Cirebon Regency, West Java. Jurnal Pengelolaan Sumberdaya Alam Dan Lingkungan (Journal of Natural Resources and Environmental 
Management), $\quad 9(1), \quad 86-91$.

https://doi.org/10.29244/jpsl.9.1.86-

91 